\title{
Financial Performance, Reputation, and Firm Value: Empirical Evidence of Non-financial Companies Listed in Indonesia Stock Exchange
}

\author{
Robert Jao' ${ }^{1}$, Djabir Hamzah' ${ }^{2}$ Abdul Rakhman Laba ${ }^{3}$, Mediaty ${ }^{4}$ \\ ${ }^{1}$ Faculty of Economics and Business, Universitas Atma Jaya, Makassar, Indonesia \\ ${ }^{1}$ Email: jao_robert@hotmail.com (Corresponding author) \\ ${ }^{2,3,4}$ Faculty of Economics and Business, Universitas Hasanuddin, Makassar, Indonesia
}

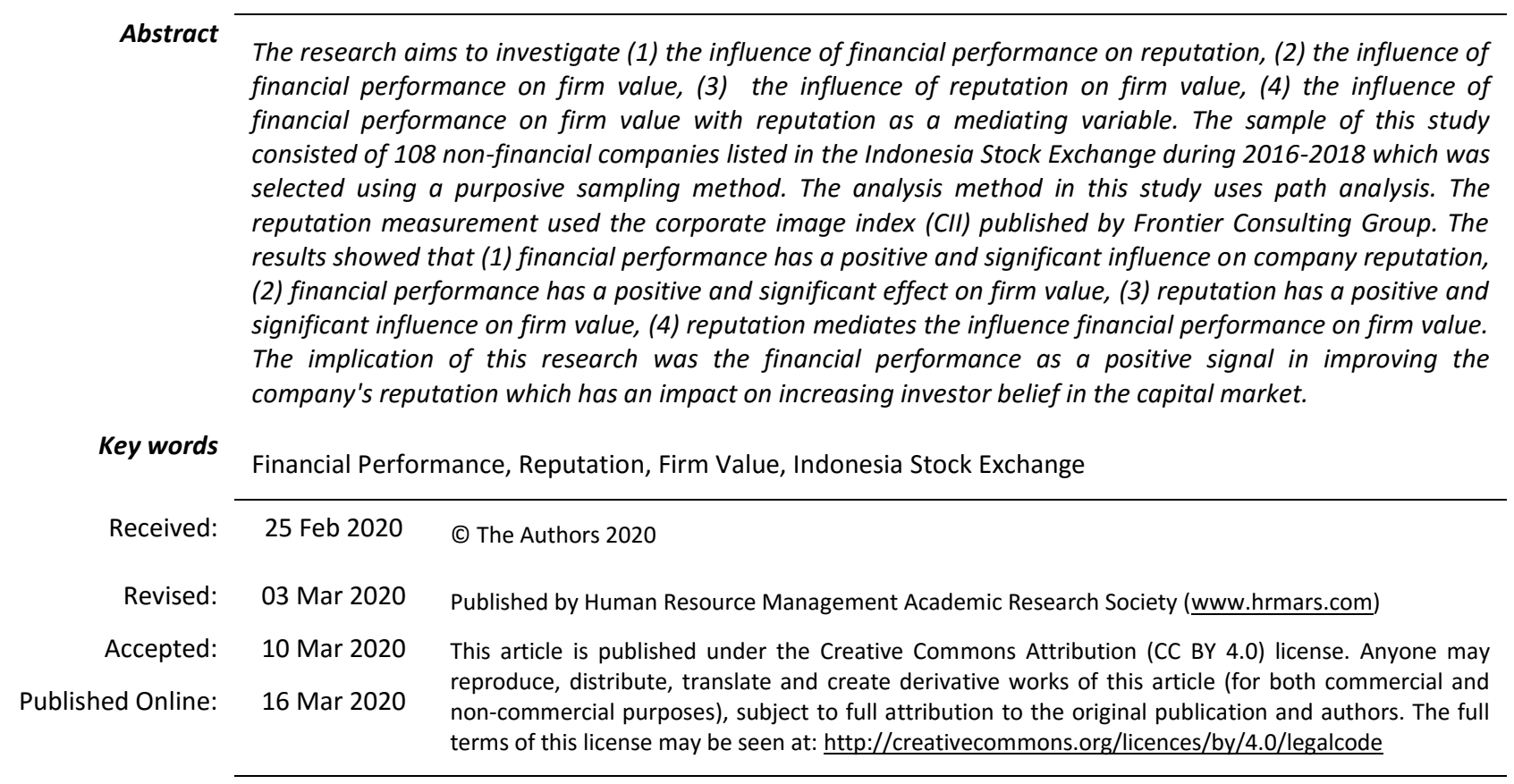

\section{Introduction}

The company has a goal of creating and maximizing firm value which is reflected in market prices (Dolenc et al., 2012). A measure of a company's success that shows how well the management is performing on behalf of its shareholders is realized through the firm value. Value creation illustrates the trust of the community towards the company after going through a series of processes that began from the time the company was founded until today (Ng \& Daromes, 2016). This shows that the goal of maximizing company value can only be achieved in the long run.

Intangible assets have a role in determining firm value (Gamayuni, 2015). Investors in the capital market pay attention to the use of intangible assets to assess the success of a business. Margaret Blair of the Brookings Institute states that seventy-five percent of the firm value comes from intangible assets (Niven, 2011). Important intangible assets are the company's reputation (Fernández-Gámez et al., 2015; Raithel and Schwaiger, 2015; Roberts and Dowling, 2002). Companies that have a good reputation can reduce uncertainty (Wang et al., 2012) and increase access to resources from stakeholders (Chong \& Halff, 2014). 
The importance of the company's reputation encourages independent institutions to give awards. Fortune Magazine published the reputation ranking of America's Most Admired Company (AMAC) since 1984 (Lee \& Roh, 2012). An award for corporate reputation in Asia was given by Asian Business by introducing Asia's Most Admired Companies (Fombrun et al., 2000). Frontier Consulting Group gave awards in the form of Indonesia's Most Admired Company (IMAC) Award or Corporate Image Award. The purpose of awarding is to encourage companies to manage their reputation in the long run.

Companies get many benefits from a positive reputation (Walker, 2010) such as making it easier for companies to build trust and build closer relationships with stakeholders. The role of reputation is increasing in the face of a competitive environment. The benefits of reputation are reflected in the long term and involve the value of the company.

Raithel and Schwaiger (2015) found that a superior reputation creates prosperity for shareholders in the form of positive abnormal returns in the long run. However, Rose and Thomsen's (2004) research controversially found inconsistent results, namely the company's reputation does not influence firm value as measured by the comparison of market value to book value.

Companies need time and effort to establish a good reputation in front of stakeholders. Good financial performance becomes a signal to stakeholders to believe that the company is good. Stakeholders have a high level of expectation towards the company and management should deliver financial results. To meet these expectations, the company must generate profits to pay the expectations of stakeholders (Hammond \&and Slocum, 1996).

Sandu and lanole (2016) found the determinant of company reputation was dominated by economic performance. This explains that stakeholders do not obtain all the information of a company so that decisions are made based on financial performance as a signal from the company as a whole. However, the results of Toms (2002) research stated that past financial performance did not create a halo effect that had an impact on reputation.

Stakeholders assess the company's financial performance through financial statements because it provides a signal regarding the level of financial health (Ames et al., 2014) and prospects (Himmah, 2018). Profit is the most commonly used performance measure. Companies that have good profitability in an industry, the stakeholders will see the company better than other companies. Also, companies that have high profitability have better resources for activities that can build a reputation such as social responsibility.

Research on corporate reputation is mostly carried out in developed countries such as the United States using company samples from America's Most Admired Companies while empirical evidence in emerging countries such as Indonesia is still lacking. This study aims to: (1) investigate the effect of financial performance on company reputation; (2) investigate the effect of financial performance on firm value; (3) investigate the effect of reputation on firm value; (4) investigate the financial performance of firm value through reputation. In the next section, we develop a framework and hypotheses based on available literature and the methods used. After that, we present the empirical results and discussion related to the findings of this study. In the final section, we draw conclusions and suggestions for future research.

\section{Conceptual Framework and Hypotheses Development}

This study uses the signaling theory (Spence, 1973) and the resource-based view (RBV) (Barney, 1991). Besides, we also use previous research and rationalization to build a framework of thought and hypothesis. Companies will use financial information to give signals to the market (Spence, 1973). The financial performance illustrates a company's ability to manage its resources. Management will provide information to interested parties regarding the company's financial performance in the form of financial statements. Financial information will be a signal about the quality of the company (McGuire et al., 1990), in this case, the company whether the company has been well managed or not. Stakeholder perceptions about the quality of the company are very dependent on the company's financial performance. Financial results represent the interests of stakeholder groups, although not all (Shi, 2016). Thus companies that have good financial performance will get a good reputation from stakeholders.

Reputation describes the overall perception of stakeholders of the company. This perception is a representation of the company's past actions and the company's status compared to its competitors. Reputation is information about the company from the perspective of signal theory and intangible assets 
from the perspective of the RBV (Piskin \& Kamanli, 2018). A good reputation becomes a signal for investors that the company has good activities, achievements, and prospects for the company so that the risk of investment in the company is low. Also, a positive reputation is a source of competitive advantage for companies because they have valuable, scarce, and not easily imitated resources. This causes the company to have loyal customers, talented employees, suppliers who are not worried when entering into contracts, and easy access to the capital market (Raithel \& Schwaiger, 2014). Companies can survive in economic conditions that experience turbulence and have competitive advantages (Fernández-Gámez, 2015). Ultimately, a good reputation will attract investors to pay higher share prices and have an impact on increasing the value of the company.

Based on the description above, the conceptual framework formed as follows:

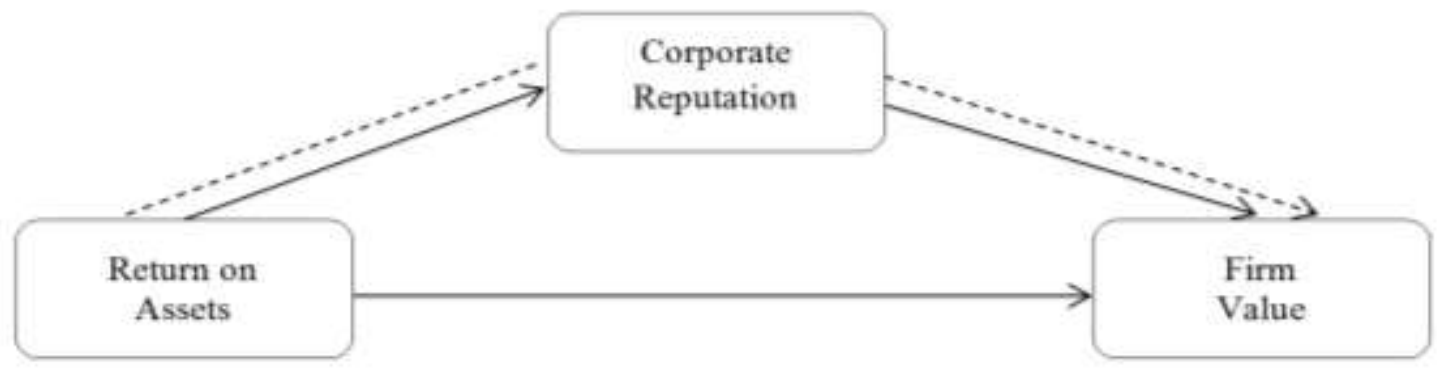

Figure 1. Conceptual Framework

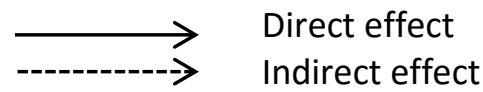

Reputation can be influenced by various factors, but the main factor that can affect reputation is financial performance (Caliskan et al., 2011). Companies with high financial performance will have a favorable reputation when compared to companies that have low financial performance. This happens because companies with positive financial performance gain trust from their stakeholders and conversely companies that have poor financial performance lose trust from their stakeholders. Roberts and Dowling's (2002); Caliskan et al. (2011); and Piskin and Kamanli (2018) found that financial performance with various measurements had a positive and significant effect on company reputation. Based on the description above, the first hypothesis proposed is:

\section{H1: Financial performance has a positive and significant effect on the company's reputation.}

Measurement of the company's financial performance can use many indicators. Net income or operating cash flow is the most commonly used performance measurement (Yu, 2013). Companies that can generate net income are considered to have good prospects in the future. Investors will use this information as a positive signal. Capital allocations owned by investors tend to be aimed at companies that have high financial performance because they obtain a certain rate of return (Purwanto \& Agustin, 2017). This has led to an increase in share prices and an impact on firm value. Haryono and Paminto (2015); Purwanto \& Agustin (2017); Susanti \& Restiana (2018); and Zuhroh (2019) found that financial performance measured using financial ratios had a positive and significant effect on firm value. Based on the description above, the second hypothesis proposed is:

\section{H2: Financial performance has a positive and significant effect on firm value.}

A company that has a good reputation can influence investors' decisions to buy shares (Erasputranto \& Hermawan, 2015). Wang et al. (2012) state that reputation has two aspects consisting of trust and attractiveness. Trust will increase investor expectations of company motivation and gain competitive advantage. On the other hand, attractiveness can reduce uncertainty about a company's ability. The company will get wider access to resources because it influences decision making and establishing better relationships with stakeholders (Raithel \& Schwaiger, 2012). Thus, a good reputation can become a valuable intangible asset and distinguish one company from another that will have an impact on increasing the value of the company's stock market. Fernández-Gámez et al. (2012); Lee \& Spirit (2012); and Raithel \& Schwaiger (2012) found that corporate reputation has a positive and significant influence on market performance and firm value. Based on the description above, the third hypothesis proposed is: 


\section{H3: Reputation has a positive and significant effect on company value.}

The reputation-financial performance dynamics model proposed by Roberts \& Dowling (2002) explains that past financial performance can affect the company's reputation and the company's reputation now can have an impact on improving the company's financial performance in the future. However, the use of accounting measurements may not reflect the benefits of a good reputation in the long run (Raithel \& Schwaiger, 2012). Thus, the benefits of a company's reputation can increase shareholder value as reflected through the stock market price. Roberts \& Dowling (2002) found that past financial performance has a significant effect on a company's reputation as well as an impact on sustained earnings in the future. Based on the description above, the fourth hypothesis proposed is:

\section{H4: Financial performance influences company value through reputation.}

\section{Methodology of research}

The population of this research is all non-financial companies listed on the Indonesia Stock Exchange (IDX) during 2016-2018. The sample selection uses a purposive sampling method with the following criteria: (1) Non-financial companies listed on the Indonesia Stock Exchange during 2016-2018 and did not delist during the observation period; (2) The company has data related to the corporate image index (CII) and other data related to research; (3) The company issues financial statements using Rupiah. Samples that met the criteria of 108 companies. This study uses observations for three years to produce 324 observation data. The type of data used is documentary data in the form of company annual reports and the Corporate Image Index published by Frontier Consulting Group. The data source of this research is secondary data obtained from the official website of the Indonesia Stock Exchange (www.idx.co.id) and Indonesia's Most Admired Companies (www.imacaward.com). Measurement of financial performance using Return on Assets (ROA) (Caliskan et al., 2011). This ratio shows the company's ability to generate income by utilizing company resources efficiently. The financial performance uses a one-year time lag with the argument that stakeholders need time to observe changes and revise assessments of the company (Flatt \& Kowalczk, 2011).

The company's reputation shows the actual views of stakeholders, both positive and negative (Walker, 2010). This study uses a corporate image index (CII) published by Frontier Consulting Group for Indonesia's Most Admired Company (Erasputranto \& Hermawan, 2015; Phandeirot, 2017). This index represents various stakeholders consisting of 3,000 respondents consisting of management, investors, journalists, and the public. The respondents conducted an assessment based on the Corporate Image Index Framework which consists of four dimensions, namely Quality, Performance, Responsibility, and Attractiveness (www.imacaward.com). The firm value is indicated by the comparison of market value against the replacement value of company assets ( $\mathrm{Ng} \&$ Daromes, 2016). The company creates value when the return obtained by shareholders is higher than the expected return. Company value is measured using Tobin's Q modified by Gaio and Raposo (2011) in the form of simple Q.

The analytical method used in this study is path analysis. The structural equation that shows the hypothesized relationship can be written as follows:

$$
\begin{aligned}
& \text { REP }=\alpha_{1} \text { ROA }+\varepsilon_{1} \\
& \text { TOB }=\beta_{1} \text { ROA }+\beta_{2} \text { REP }+\varepsilon_{2}
\end{aligned}
$$

\section{Research results and discussions}

Descriptive statistical analysis is used to present quantitative data that can provide an overview of the sample company. Descriptive statistics consist of the mean, maximum, minimum, and standard deviation of the variables studied. Table 1 presents descriptive statistics of the variables of financial performance, reputation, and firm value. Measurement of financial performance using ROA shows an average of 0.054 . These results illustrate that the company's ability to generate net income of $5.4 \%$ of assets owned. The reputation of companies that use the corporate image index (CII) shows an average value of 1.283. The higher the Cll the company gets, the better the stakeholder's perception of the company. If the company gets more than one $\mathrm{Cll}$ and is in the top three in each group, the company is in 
the excellent category. The firm value measured by Tobin's $Q$ shows an average value of 1.623 . If Tobin's $Q$ has a value above one, the company is valued higher than the book value.

Table 1. Descriptive Statistics

\begin{tabular}{|c|c|c|c|c|c|}
\hline Variable & $\boldsymbol{N}$ & Minimum & Maximum & Mean & Std. Deviation \\
\hline ROA & 324 &,- 549 &, 458 &, 054 &, 0101 \\
\hline REP & 324 &, 210 & 3,316 & 1,283 &, 650 \\
\hline TOB & 324 &, 201 & 5,006 & 1,623 & 1,077 \\
\hline
\end{tabular}

Source: Output SPSS (2020)

Hypothesis testing is performed using a regression model in path analysis to predict the relationship between the independent variable and the dependent variable. The path analysis results in this study are presented in Table 2.

Table 2. Path Analysis Results

\begin{tabular}{lclc}
\hline \multicolumn{1}{c}{ Model } & Standardized Beta & Sig. & Explanation \\
\hline $\mathrm{ROA}^{\rightarrow}$ REP & .357 & .000 & Signifikan \\
\hline $\mathrm{ROA}^{\rightarrow}{ }_{\mathrm{TOB}}$ & .448 & .000 & Signifikan \\
$\mathrm{REP}^{\rightarrow}{ }_{\mathrm{TOB}}$ & .170 & .001 & Signifikan \\
\hline
\end{tabular}

Source: Output SPSS (2020)

Financial performance measured using ROA has a significant positive effect on the company's reputation. These results indicate that a company that has good financial performance will enhance its reputation. The results of this study are consistent and in line with Hammod \& Slocum (1996); Roberts \& Dowling (2002); Caliskan et al. (2011); Shi (2016); and Piskin \& Kamanli (2018) who found that financial performance had a positive and significant effect on company reputation. A company that has high financial performance will have a good reputation in front of its stakeholders. If the company produces good financial performance, this will be a positive signal about the quality of the company in the eyes of stakeholders. The quality of the company will increase the trust of its stakeholders. The company is considered to be able to produce quality goods and services, be able to innovate products, have opportunities to grow, manage good business, care about social responsibility, and become a desirable workplace.

Financial performance has a positive and significant effect on the firm value measured using Tobin's Q. Companies that have good financial performance will increase firm value in the capital market. This result is consistent with Haryono \& Paminto (2015); Purwanto \& Agustin (2017); Susanti \& Restiana (2018); and Zuhroh (2019) who found that financial performance using profitability ratios significantly had a positive effect on firm value. Companies that have good financial performance become a positive signal for investors so they are interested to invest their capital in the company. Investors also believe that companies producing high income will distribute dividends. Thus, the higher the company's ability to generate income, the higher the company's expectations of return that will make the firm value better.

The company's reputation has a positive and significant influence on firm value. Companies that have a good reputation in front of their stakeholders will increase the value of the company. These results are consistent with Fernández-Gámez et al. (2012); Lee \& Spirit (2012); and Raithel \& Schwaiger (2012) find that corporate reputation has a positive and significant influence on the firm value. This shows that a company that has a good reputation will increase the firm value that is realized by rising stock market prices. Companies with a positive reputation in front of their stakeholders mean having valuable, rare, intangible assets that are not easily imitated by competing companies (Barney, 1991) which are a source of sustainable competitive advantage. The company is closed and gets the trust of stakeholders so that it can influence decision making. Also, companies that have a good reputation are considered to have low risk. This trust is what attracts investors to choose to invest their capital and is willing to pay a higher price.

Sobel test is used to test the strength of the indirect effect of financial performance on the value of the company through reputation. If the $p$-value $<0.05$, it can be concluded that reputation has successfully 
mediated the relationship between financial performance and firm value. The Sobel test results are presented in Table 3.

Table 3. Sobel Test

\begin{tabular}{cc}
\hline \multicolumn{1}{c}{ Variable } & p-value Of Sobel Test (two-tailed probability) \\
\hline ROA $^{\rightarrow}$ TOB (Via REP) & .0025 \\
\hline
\end{tabular}

Source: Sobel test calculators version 4.0 (2020)

Table 3 shows the significant value of the Sobel test of 0.0025 . These results indicate that the company's reputation can mediate the influence of the financial performance board on firm value. These results are consistent with Roberts \& Dowling's (2002) research that describes a dynamic model of financial reputation-performance where financial performance in the past affects the company's reputation and the company's reputation will consistently provide superior results for the company. Achievements of the company in the past will leave perceptions about the quality of the company and this will build trust in the company's actions in the future (Raithel \& Schwaiger, 2015). Thus, companies that can build a good reputation, the company can influence the decision making of its stakeholders.

\section{Conclusions}

This research was conducted to investigate the effect of financial performance on firm value by using reputation as a mediating variable. The sample in this study were 108 companies or 324 observation data. Good financial performance can improve the reputation and value of the company. A good financial performance becomes a positive signal so that the company gains trust in front of its stakeholders and attracts investors' attention to invest their capital in the company. Companies with a good reputation will get many strategic benefits and have a competitive advantage. This good reputation then attracts the attention of investors and is willing to buy shares at a high price. The company's reputation can mediate the effect of financial performance on firm value. The company's performance in the past will be a signal regarding the quality of the company. Stakeholder confidence in the quality of the company will have an impact on the market value of the company. Future research can use sustainable financial performance measures such as earnings persistence. Also, this research only focuses on non-financial companies with observations for three years. Subsequent research can use a sample of financial companies and a longer observation time.

\section{References}

1. Ames, D. S., Hines, C., \& Sankara, J. (2014). Are Earnings Quality Attributes Reflected in Financial Strength Ratings. American Journal of Business, 29(3/4), 293-311.

2. Barney, J. (1991). Firm Resources and Sustained Competitive Advantage. Journal of Management, 17(1), 99-120.

3. Caliskan, E., Icke, B., \& Ayturk, Y. (2011). Corporate Reputation and Financial Performance: Evidence from Turkey. Research Journal of International Studies, 18, 61-72.

4. Chong, M., \& Halff, J. G. (2014). Start-up Reputations in Asian Markets. Asian Management Insights, 1, (2), 76-81. Research Collection Lee Kong Chian School of Business. Available at: http://ink.library.smu.edu.sg/lkcsb_research/4358

5. Dolenc, P., Stubelj, I., \& Laporšek, S. (2012). What is the Objective of a Firm? Overview of Theoretical Perspectives. Overcoming the Crisis, 51.

6. Erasputranto, R. A., \& Hermawan, A. (2015). The Effect of Corporate Image on Company's Stock Return. Simposium Nasional Akuntansi XV, Medan, 16-19 September 2015.

7. Fernández-Gámez, M. A., Gil-Corral, A. M., \& Galán-Valdivieso, F. (2015). Corporate Reputation and Market Value: Evidence with Generalized Regression Neutral networks. Expert Systems with Applications, 46, 69-76.

8. Flatt, S. J., \& Kowalczyk, S. J. (2011). Corporate Reputation Persistence and Its Diminishing Returns. International Journal of Business and Social Science, 2(19). 
9. Fombrun, C. J., Gardberg, N. A., \& Sever, J. M. (2000). The Reputation Quotient SM: A Multistakeholder Measure of Corporate Reputation. Journal of Brand Management, 7(4), 241-255.

10.Gaio, C., \& Raposo, C. (2011). Earnings Quality and Firm Valuation: International Evidence. Accounting \& Finance, 51(2), 467-499.

11.Gamayuni, R. R. (2015). The Effect of Intangible Asset, Financial Performance and Financial Policies on the Firm Value. International Journal of Scientific and Technology research, 4(1), 202-212.

12.Hammond, S. A., \& Slocum, J. W. (1996). The Impact of Prior Firm Financial Performance on Subsequent Corporate Reputation. Journal of Business Ethics, 15(2), 159-165.

13.Himmah, E. F. (2018). An Analysis of the Effect of Earnings Persistence, Good Corpoarate Governance, and Accrual Component to Earnings Quality on Banking In Indonesia In 2011-2015. Jurnal Riset Akuntansi Dan Bisnis Airlangga, 3(1).

14. Haryono, U., \& Paminto, A. (2015). Corporate Governance and Firm Value: The Mediating Effect of Financial Performance and Firm Risk. European Journal of Business and Management, 7(35), 18-24.

15.Lee, J., \& Roh, J. (2012). Revisiting Corporate Reputation and Firm Performance Link. Benchmarking: An International Journal, 19(4/5), 649-664.

16.McGuire, J. B., Schneeweis, T., \& Branch, B. (1990). Perceptions of Firm Quality: A Cause or Result of Firm Performance. Journal of Management, 16(1), 167-180.

17.Ng, S., \& Daromes, F. E. (2016). Peran Kemampuan Manajerial sebagai Mekanisme Peningkatan Kualitas Laba dan Nilai Perusahaan. Jurnal Akuntansi dan Keuangan Indonesia, 13(2), 174-193.

18.Niven, P. R. (2011). Balanced Scorecard: Step-by-step for Government and Nonprofit Agencies. John Wiley \& Sons.

19.Phandeirot, M. (2017). Pengaruh Ceo Duality, Earning Management dan Corporate Reputation terhadap Financial Performance pada Perusahaan yang Terdaftar di Bursa Efek Indonesia. Petra Business and Management Review, 3(1)

20.Piskin, A., \& Kamanli, A. I. (2018, June). The Financial Performance-Corporate Reputation Nexus in Turkey. In Proceedings of International Academic Conferences (No. 6408847). International Institute of Social and Economic Sciences.

21.Purwanto, P., \& Agustin, J. (2017). Financial Performance towards Value of Firms in Basic and Chemicals Industry. European Research Studies, 20(2), 443-460.

22.Raithel, S., \& Schwaiger, M. (2015). The Effects of Corporate Reputation Perceptions of The General Public on Shareholder Value. Strategic Management Journal, 36(6), 945-956.

23.Roberts, P. W., \& Dowling, G. R. (2002). Corporate Reputation and Sustained Superior Financial Performance. Strategic Management Journal, 23(12), 1077-1093.

24.Rose, C., \& Thomsen, S. (2004). The Impact of Corporate Reputation on Performance: Some Danish Evidence. European Management Journal, 22(2), 201-210.

25.Sandu, M., \& lanole, R. (2016). What Really Matters for a Good Corporate Reputation? A Structural Equation Modelling View. Journal of Social and Economic Statistics, 5(2), 16-32.

26.Shi, Y. (2016). Reputation, Financial Performance, and Industry Competition. The International Journal of Business and Finance Research, 10 (2), 1-16

27.Spence, M. (1973). Job Market Signaling. The Quarterly Journal of Economics, 87(3), 355-374.

28.Susanti, N., \& Restiana, N. G. (2018). What's the Best Factor to Determining Firm Value?. Jurnal Keuangan dan Perbankan, 22(2).

29.Toms, J. S. (2002). Firm Resources, Quality Signals and the Determinants of Corporate Environmental Reputation: Some UK Evidence. The British Accounting Review, 34(3), 257-282.

30.Walker, K. (2010). A Systematic Review of the Corporate Reputation Literature: Definition, Measurement, and Theory. Corporate Reputation Review, 12(4), 357-387.

31.Wang, Y., Berens, G., \& Van Riel, C. B. (2012). Competing in the Capital Market with a Good Reputation. Corporate Reputation Review, 15(3), 198-221.

32.Yu, M. (2013). State Ownership and Firm Performance: Empirical Evidence from Chinese Listed Companies. China Journal of Accounting Research, 6(2), 75-87.

33.Zuhroh, I. (2019). The Effects of Liquidity, Firm Size, and Profitability on the Firm Value with Mediating Leverage. KnE Social Sciences, 203-230. 
International Journal of Academic Research in Accounting, Finance and Management Sciences Vol. 10 (1), pp. 117-124, @ 2020 HRMARS (www.hrmars.com)

wWw.idx.co.id

www.imacaward.com 